\begin{tabular}{ll}
\hline Jor $8(2)(2019)$ \\
Jttp://journal.unnes.ac.id/sju/index.php/jsi
\end{tabular}

\title{
Perlawanan Perempuan terhadap Dominasi Patriarki dalam Novel Geni Jora Karya Abidah El Khalieqy Kajian Feminisme Psikoanalisis Karen Horney
}

\author{
Bayu Aji Nugroho ${ }^{凶}$
}

Fakultas Ilmu Budaya, Universitas Mulawarman, Indonesia

\begin{tabular}{|c|c|}
\hline Info & \\
\hline & \multirow{6}{*}{$\begin{array}{l}\text { Penelitian ini berjudul "Perlawanan Perempuan Terhadap Dominasi Patriarki dalam Novel Geni } \\
\text { Jora Karya Abidah El Khalieqy Kajian Feminisme Psikoanalisis Karen Horney. Konflik perlawanan } \\
\text { yang dilakukan oleh tokoh perempuan di analisis menggunakan teori psikoanalisis feminisme Karen } \\
\text { Horney. Penelitian ini bertujuan untuk mencari korelasi antara karakter perempuan dalam novel } \\
\text { dengan perlawanan terhadap dominasi patriarki yang dialami perempuan. Metode dalam penelitian } \\
\text { ini adalah metode Deskriptif Kualitatif, di mana peneliti berupaya mendeskripsikan hasil dari } \\
\text { bacaan terhadap sumber data primer dan sekunder kemudian mengolah dalam bentuk data } \\
\text { kualitatif. Secara teoretis peneliti menggunakan teori feminisme psikoanalisis Karen Horney yang } \\
\text { menyatakan bahwa perlawanan perempuan didasarkan atas pola asuh dan lingkungan sosial di } \\
\text { mana perempuan tersebut tinggal. Perlawanan perempuan secara psikoanalisis dibagi dalam tiga } \\
\text { bentuk perlawanan antara lain, pergerakan mendekati orang lain, melawan orang lain, dan menjauhi } \\
\text { orang lain. Dampak dari perlawanan tersebut, mengakibatkan perempuan mengalami berbagai } \\
\text { macam mekanisme pertahanan diri seperti, pemindahan, sublimasi, identifikasi, represi, dan } \\
\text { proyeksi. }\end{array}$} \\
\hline & \\
\hline & \\
\hline Dipuo & \\
\hline $\begin{array}{l}\text { patria } \\
\text { femin }\end{array}$ & \\
\hline vwords. & \\
\hline
\end{tabular}

\section{Abstract}

This research is entitled "Women's Resistance to Domination of Patriarchy in Geni Jora's Novel by Abidah El Khalieqy Study of Feminism in Psychoanalysis Karen Horney. Conflicts of resistance carried out by female figures were analyzed using Karen Horney's psychoanalytic theory. This research aims to find the correlation between female characters in the novel with resistance to patriarchal domination experienced by women. The method used in this research was a Qualitative Descriptive method, where the researcher attempted to describe the results of the reading of the primary and secondary data sources then processed them in the form of qualitative data. Theoretically, the researcher used the theory of psychoanalytic feminism Karen Horney who stated that women's resistance is based on parenting and the social environment where the woman lives. Psychoanalytic resistance of women was divided into three forms of resistance, among others, the way of approaching others, against others, and away from others. The impact of this resistance has resulted in women experiencing a variety of self-defense mechanisms such as transfer, sublimation, identification, repression and projection.

(C) 2019 Universitas Negeri Semarang

$\begin{array}{ll}凶 \text { Alamat korespondensi: } & \text { P-ISSN 2252-6315 } \\ \text { Jalan Pulau Flores No 1 Samarinda 75112 } & \text { E-ISSN 2685-9599 } \\ \text { E-mail: bayuajinugroho@fib.unmul.ac.id } & \end{array}$




\section{PENDAHULUAN}

Sastra merupakan hasil pemikiran dan perenungan pengarang terhadap berbagai peristiwa yang terjadi di dunia nyata. Karya sastra yang dihasilkan tersebut tidak terlepas dari kondisi sosial budaya yang melatarbelakanginya. Sebagai anggota masyarakat, pengarang tentunya memiliki pendapat tersendiri mengenai situasi dan masalah yang terjadi di lingkungannya. Berbagai pendapat dan pengalaman tentang kehidupan dimaknai lalu dituangkan dalam bentuk karya sastra yang tentunya sudah dibumbui dengan peristiwa imajinatif dan kreatif dari pengarang. (Nurgiyantoro, 1995: 19-20)

Penyerapan keadaan sosial melalui karya sastra merupakan hal yang harus diperhatikan pengarang, sebab pengarang menulis berdasarkan peristiwa faktual kemudian diubah ke dalam bentuk yang bersifat imajinasi. Hal ini sesuai dengan fungsi karya sastra yaitu berguna dan memberikan hiburan bagi pembaca (dulce et utile). Begitu pun ketika di berbagai belahan dunia terjadi arus gelombang perlawanan, khususnya pemberontakan terhadap sistem patriarki yang dipelopori kaum feminis.

Dalam berbagai wilayah kehidupan baik sosial, politik, ekonomi, agama, maupun budaya, posisi perempuan selalu dimarjinalkan di bawah dominasi superioritas kaum laki-laki. Kondisi yang telah mapan inilah yang hendak diubah oleh para aktivis perempuan yang merasa peduli dengan nasib kaum sesamanya yang pada akhirnya memunculkan gerakan feminisme. Feminisme muncul sebagai upaya perlawanan dan pemberontakan atas berbagai kontrol dan dominasi kaum laki-laki terhadap kaum perempuan yang dilakukan berabad-berabad lamanya. Gerakan feminisme ini pada awalnya berasal dari asumsi yang selama ini dipahami bahwa perempuan bisa ditindas dan dieksploitasi dan dianggap makhluk kelas dua. Maka feminisme diyakini sebagai langkah untuk mengakhiri penindasan tersebut (Tong, 2006 : 97).

Dasar pemikiran dalam penelitian sastra berspektif feminis adlah upaya pemahaman kedudukan dan peran perempuan seperti tercermin dalam karya sastra. Pertama, kedudukan dan peran para tokoh perempuan dalam karya sastra Indonesia masih didominasi oleh laki-laki. Kedua, dari resepsi pembaca karya sastra Indonesia secara sepintas, terlihat bahwa para tokoh perempuan dalam karya sastra Indonesia tertinggal dari laki-laki. Ketiga, masih ada resepsi pembaca karya sastra Indonesia yang menunjukan bahwa hubungan antara laki-laki dan perempuan hanyalah merupakan hubungan yang didasarkan pada pertimbangan biologis dan sosial-ekonomis semata. Keempat, penelitian sastra Indonesia telah melahirkan banyak perubahan analisis dan metodologinya, salah satunya adalah penelitian sastra berperspektif feminis.

Menurut Salden dalam Pradopo (2002: 137) pengkajian sastra berspektif feminis terdiri atas lima fokus (1) biologi, yang sering menempatkan perempuan lebih inferior, lembut, lemah, dan rendah, (2) pengalaman, seringkali wanita dipandang memiliki pengalaman terbatas, masalah mentruasi, melahirkan, menyusui, dan seterusnya, (3) wacana, biasanya wanita lebih rendah penguasaan bahasa, sedangkan laki-laki memiliki "tuntutan kuat". Akibat dari semua ini, akan menimbulkan steorotip yang negative para diri wanita, wanita sekedar kanca wingking, (4) proses ketidaksadaran, secara diam-diam penulis feminis telah meruntuhkan otoritas laki-laki. Seksualitas wanita bersifat revolusioner, subversif, beragam, dan terbuka. Walaupun demikian, hal ini masih kurang disadari oleh lakilaki, (5) pengarang feminis biasanya sering menghadirkan tuntutan sosial dan ekonomi yang berbeda dengan laki-laki. Dari berbagai focus tersebut, peneliti sastra yang berhaluan feminis dapat memusat pada beberapa pilihan saja agar lebih mendalam.

Pemikiran tentang gerakan pembebasan perempuan ini turut pula berimbas pada berbagai ranah kehidupan sosial, politik, budaya, dan termasuk karya sastra yang notabene merupakan salah satu wujud kebudayaan. Hal ini dapat dimaklumi karena sebuah karya sastra bisa dikatakan wadah untuk menanggapi berbagai peristiwa yang berkecamuk dalam kehidupan nyata yang sekaligus sebagai kritik sosial dari sang pengarang. Seperti yang dikemukakan oleh Wellek dan Austin (1989: 109), sastra menyajikan kehidupan, dan arti kehidupan sebagian besar terdiri atas kenyataan sosial 
walaupun karya sastra juga meniru alam dan subjektif manusia.

Kehidupan Kejora dan budaya patriarki yang didapat dari keluarga, teman, dan saudaranya membuat Kejora menjadi sosok perempuan yang mampu menunjukan eksistensi dirinya sebagai sosok perempuan tangguh. Kejora telah melawan berbagai bentuk diskriminasi yang dialaminya dengan cara yang cerdas.

Kejora merupakan satu di antara tipikal perempuan Indonesia dengan latar yang berbeda. Ikatan kesepian masa kecil dalam tembok kolaborasi feodalisme gaya Timur Tengah dan Jawa Timur yang menjeratnya, menjadikannya subordinat dari komunitas kaum lelaki. Geni Jora sebagai novel juga sangat menarik untuk dinikmati atau pun dikaji sebagai pembelajaran dalam khasanah kehidupan.

Nilai-nilai feminisme terhadap dominasi budaya patriarki yang terdapat dalam novel Geni Jora karya Abidah El Khalieqy dalam menghadapi penguasaan dari tokoh lelaki dalam novel tersebut membuat peneliti berkeinginan untuk meneliti "Perlawanan Perempuan Terhadap Dominasi Patriarki Dalam Novel Geni Jora Karya Abidah El Khalieqy Kajian Feminisme Psikoanalisis Karen Horney".

Berdasarkan latar belakang masalah yang dikemukakan di atas, perumusan masalah dalam penelitian adalah mengkaji bentuk perlawanan perempuan terhadap Dominasi Patriarki dalam Novel Geni Jora Karya Abidah El Khalieqy dengan menggunakan analisis Feminisme Psikoanalisis Karen Horney dan faktor-faktor apa saja yang mempengaruhi perempuan untuk melakukan perlawanan dalam Novel Geni Jora Karya Abidah El Khalieqy dengan menggunakan analisis Feminisme Psikoanalisis Karen Horney.

Landasan teori dalam penelitian ini adalah teori psikoanalisis sosial dari Karen Horney yang dibentuk berdasarkan asumsi bahwa kondisi sosial dan kultural, terutama pengalamanpengalaman masa kanak-kanak, sangat besar pengaruhnya dalam membentuk kepribadian seseorang. Orang-orang yang tidak mendapatkan kebutuhan akan cinta dan kasih sayang yang cukup selama masa kanak-kanak mengembangkan rasa permusuhan dasar (basic hostility) terhadap orang tua mereka dan sebagai akibatnya mengalami kecemasan dasar (basic anxiety). Pengalaman masa kanak-kanak awal mempunyai peranan penting dalam membentuk kepribadian manusia menjadi kepribadian sehat (Horney dalam Feist, 2010 : 192).

Konflik neurotik dapat muncul dari hampir semua tahapan perkembangan, tetapi masa kanak-kanak adalah masa di mana sebagian besar masalah timbul. Peristiwa traumatis yang berbeda-beda, seperti pelecehan seksual, pemukualan, penolakan atau pengabaian, dapat mempengaruhi perkembangan anak di masa depan. Pengalaman-pengalaman yang merusak ini hampir selalu ditimbulkan oleh kurangnya kehangatan dan kasih sayang yang tulus (Horney dalam Feist, 2010 : 197-198).

Manusia membutuhkan kondisi-kondisi yang mendukung untuk berkembang. Kondisi ini harus mencakup lingkungan yang hangat dan saling mencintai. Anak-anak perlu merasakan cinta yang tulus dan kedisiplinan yang baik. Kondisi-kondisi seperti ini akan memberikan perasaan aman dan puas kepada mereka dan memungkinkan mereka tumbuh sesuai dengan diri mereka sebenarnya (real self). Namun, sejumlah pengaruh buruk dapat menggangu kondisi-kondisi yang mendukung tersebut. Menurut Horney dalam Feist (2010 : 143), manusia memerangi kecemasan dasar dengan mengadopsi satu dari tiga jenis relasi dengan orang lain, bergerak menuju orang lain (moving toward people), bergerak menentang orang lain (moving against people), dan bergerak menjauh dari orang lain (moving away from people).

\section{METODE}

Metode penelitian yang digunakan dalam pendekatan penelitian ini adalah deskriptif kualitatif. Pengkajian deskriptif menyarankan pada pengkajian yang dilakukan semata-mata hanya berdasarkan pada fakta atau fenomena yang secara empiris hidup pada penuturnya (sastrawan). Artinya, yang dicatat dan dianalisis adalah unsur-unsur dalam karya sastra seperti apa adanya. Penelitian yang akan dibahas 
bertujuan untuk mengurai benang kusut permasalahan perlawanan perempuan yang selama ini berkembang di masyarakat secara spesifik, kemudian disertai dengan bukti yang menunjukan faktor-faktor penyebab perlawanan perempuan dalam Novel Geni Jora karya Abidah El Khalieqy.

Dalam menganalisis data pada novel Geni Jora karya Abidah El Khalieqy adalah teknik analisis deskriptif. Teknik analisis deskriptif digunakan untuk mengungkapkan bentuk feminisme, dan bentuk dominasi patriarki di dalam teks, kemudian dianalisis dengan menggunakan teori feminis dan setelah itu ditentukan bentuk dominasi serta ungkapan femin. Teknis analisis data yang digunakan dalam menganalisis data pada novel Geni Jora karya Abidah E1 Khalieqy adalah teknik analisis deskriptif.

Teknik analisis deskriptif digunakan untuk mengungkapkan bentuk feminisme, dan bentuk dominasi patriarki di dalam teks, kemudian dianalisis dengan menggunakan teori feminis dan setelah itu ditentukan bentuk dominasi serta ungkapan feminis. Adapun prosedur analisis data pada penelitian dalam ini adalah sebagai berikut

1. Membaca teks sastra (dalam hal ini adalah novel Geni Jora).

2. Menganalisis perlawanan perempuan yang terdapat di dalam novel Geni Jora terhadap dominasi patriarki kajian feminisme psikoanalisis.

3. Menganalisis faktor-faktor penyebab perlawanan perempuan dalam novel Geni Jora.

4. Membuat simpulan hasil analisis.

\section{HASIL DAN PEMBAHASAN}

\section{Representasi Perlawanan Perempuan Dalam Novel Geni Jora.}

Adanya ketidakadilan gender yaitu dikotomi antara perempuan dan laki-laki yang disejajarkan dengan dikotomi peran domestikpublik, dan masih adanya kekerasan terhadap perempuan dari kaum laki-laki, menyebabkan masih dirasakan adanya perlakuan yang berbeda antara laki-laki dan perempuan. Semua itu menimbulkan berbagai macam bentuk perlawanan dari perempuan dalam memperjuangkan kesetaraan gender. Begitupun yang dilakukan tokoh perempuan dalam novel Geni Jora karya Abidah El Khalieqy.

Bentuk representasi nilai-nilai feminisme yang dilakukan oleh Kejora yang berusaha memperjuangkan kesetaraan gender dengan melakukan perlawanan terhadap konstruksi gender, yaitu berupa perlawanan terhadap ketidakadilan gender. Berikut bentuk representasi nilai-nilai feminisme tokoh perempuan dalam novel Geni Jora karya Abidah El Khalieqy yang meliputi perlawanan mendekati orang lain (moving forward people), melawan orang lain (against people), dan menjauhi orang lain (moving away from people).

\section{Mendekati Orang lain (Moving Forward People)}

Dalam novel Geni Jora tokoh Kejora melakukan perlawanan yaitu mendekati orang lain terhadap salah satu bentuk ketidakadilan gender yang dialaminya yaitu perlawanan terhadap ketidakadilan gender dalam bentuk marginalisasi terhadap perempuan yang tergambarkan oleh sosok Kejora. Kejora adalah perempuan tangguh yang berusaha menentang berbagai bentuk pemiskinan terhadap perempuan. Bentuk pemiskinan tersebut terlihat di dalam novel Geni Jora melalui cerita, di mana perempuan di dalam novel dibatasi haknya dalam urusan publik. Salah satu bentuk representasi nilai-nilai feminisme dalam melawan bentuk marginalisasi terlihat dalam kutipan berikut.

"Siapa ibumu, Jora?"

Ibumu seorang perempuan sederhana yang mengelola rumahnya menjadi sebuah kastil indah bagi anak-anak dan suaminya. Ia tidak pernah pergi kemana-mana. Ia melangkahi pintu besar hanya diwaktu takziah, pesta pernikahan atau menjadi imam shalat Jumat di langgar (musala) yang khusus untuk perempuan. Hampir seluruh waktu ibuku habis untuk anak-anaknya. Kamilah putra-putrinya, hiburan terbesar baginya (Khalieqy, 2004 : 79).

Bentuk marginalisasi di mana perempuan diposisikan sebagai makhluk domestik sebagai ibu rumah tangga. Dalam melawan bentuk marginalisasi tersebut tokoh Kejora berupaya 
mendekati tokoh ayah dengan selalu bersikap manis dan menjadi anak penurut.

Bangun dalam sepertiga, itu sangat bagus, tetapi bukan untuk sensasi. Bangun malam adalah qiyamullail, tahajud! Tafakur! Tadarus! Bukan keluyuran membikin berita heboh, mengganggu para tetangga, menggangu saudara-saudaranya yang tengah nyenyak tidur. Itu namanya merusak malam (Khalieqy, 2004 : 74).

Pola didikan orang tua yang keras menjadikan Kejora sebagai anak yang tampak patuh terhadap perintah ayahnya, meskipun dalam hati dan pikiran Kejora selalu berseberangan dengan pemikiran dan pendapat ayahnya. Hal tersebut dikarenakan adanya konstruksi gender yang bersifat patriarkis yang menempatkan perempuan sebagai kelas kedua, inferior, dan harus selalu mengalah dalam hubungannya dengan laki-laki. Bentuk patriarki yang muncul dalam kutipan di atas menunjukan bentuk marginalisasi di mana penguasaan atas wilayah publik didominasi oleh laki-laki.

Dampak dari perlawanan Kejora terhadap bentuk marginalisasi secara psikologis adalah tindakan pemindahan atau displacement di mana Kejora berusaha meredakan ketegangan yang muncul di dalam dirinya dengan melampiaskan kepada orang lain. Dalam novel Geni Jora, tokoh Kejora melampiaskan bentuk pemindahan atau displacement terhadap tokoh Wak Girun pembantu yang berkerja di rumah Kejora.

"Hai Gendut! Apa yang lucu dari durian hingga buncitmu berguncang-guncang?” aku melengking dari bawah.

Wak Girun yang memiliki perut menggelembung itu kaget, untung tidak sampai lepas pegangan, begitu menyadari aku berada di bawahnya, tengah memperhatikan dia (Khalieqy, 2004 : 75-76).

Bentuk displacment dikarenakan terdapat pemindahan pelampiasan ketegangan atau adanya proses kateksis dari amarah Kejora kepada objek yang lebih rendah kedudukannya, yaitu kepada Wak Girun sebagai pembantu rumah tangga.

\section{Perlawanan Melawan Orang Lain (Against People) \\ Dalam upaya melakukan perlawanan} terhadap orang lain tokoh utama Kejora dalam novel Geni Jora melakukan perlawanan terhadap berbagai bentuk penempatan perempuan sebagai kelas kedua yang sangat tampak dalam kehidupan Kejora. Kejora sebagai anak perempuan selalu ditempatkan sebagai kelas kedua dibanding adik laki-lakinya. Hal tersebut tampak dalam kutipan berikut.

"Dengar, Nenekku sayang. Sebuah rahasia akan kubeberkan di hadapanmu. Nenek mau?"

"Sebuah rahasia? Rahasia apa itu, Cucu?"

"Bahwa Prahara bukanlah ranking kesatu, tetapi aku. Kejora" (Khalieqy, 2004 : 62).

Bentuk penempatan perempuan sebagai kelas kedua yang membuat Kejora melakukan perlawanan secara langsung. Perlawanan langsung tersebut ditunjukan dengan sanggahan terhadap ucapan nenek mengenai penempatan perempuan sebagai kelas kedua di dalam keluarga Kejora.

“Akulah sang juara itu. Nenek mau bukti?" "Mana?Mana buktinya?"

Lalu kubentangkan nilai raportku dihadapannya berikut raport Prahara dan surat peringatan dari $\mathrm{Bu}$ Guru.... 'Inikan nilai raport sekolahan, Cucu. Berapa pun nilai Prahara di sekolahan, sebagai laki-laki, ia tetap ranking pertama di dunia kenyataan. Sebaliknya kau. Berapapun rangkingmu, kau adalah perempuan dan akan tetap sebagai perempuan (Khalieqy, 2004 : 62).

Adanya sterotip yang melabeli dirinya dan perempuan pada umumnya tidak membuat Kejora diam dan menerima. Kutipan tersebut juga menunjukan adanya perlawanan terhadap orang lain (against people) di mana tokoh Kejora melakukan perlawanan secara langsung terhadap tokoh nenek dengan menentang argumen nenek tentang tingkatan gender dalam keluarga Kejora. Kejora tetap selalu berusaha menunjukkan bahwa dirinya selalu menjadi nomer satu dari adik laki-lakinya.

Untuk membuktikan dan lebih menyakinkan bahwa Prahara memiliki rangking di bawahku, aku telah mampu menunaikan salat lima waktu saat usiaku genap tujuh tahun. Aku juga rajin puasa sunnah Senin-Kamis dan tengah bulan Qamariah (Khalieqy, 2004 : 63) 
Upaya Kejora dalam membuktikan bahwa dirinya mampu menjadi lebih baik dari adiknya Prahara merupakan sebuh bentuk perlawanan secara langsung. Dalam usianya yang baru sembilan tahun, digambarkan Kejora sudah mencoba untuk merefleksikan posisi dirinya dan kaum perempuan di masyarakatnya yang selalu dinomorduakan.

\section{Menjauhi Orang Lain (Moving Away From People)}

Perempuan bukan makhluk lemah yang bisa diperlakukan sesuai hasrat seksual pria. Perempuan dapat melawan apabila terancam harga dirinya. Kejora sosok perempuan yang menunjukkan perlawanan terhadap konstruksi gender yaitu, sterotip publik yang menimpa dirinya.

Perlawanan itu menunjukkan bahwa perempuan dapat keluar dari bentuk konstruksi gender yang tidak adil selama ini, yang telah berkembang di masyarakat. Secara istilah diksi perempuan terbentuk dari kata wanita (wani ditata) yang berarti perempuan dapat dikendalikan dan diperlakukan sesuai dengan keinginan kaum pria.

Dalam upaya melakukan perlawanan yaitu menjauhi orang lain (moving away from people) tokoh Kejora melakukan perlawanan terhadap kekerasan yang dialaminya baik berupa kekerasan fisik, psikis, dan seksual. Kejora juga menunjukkan bahwa perempuan bukan makhluk yang lemah yang hanya dapat menangis dan menerima nasib yang terjadi padanya.

Perlawanan menjauhi orang lain bukan berarti tidak melawan atau diam. Kejora menunjukkan sudut pandang perempuan yang berbeda. Kejora adalah perempuan yang tidak lemah dan menerima begitu saja ketidakadilan yang dialaminya dari tokoh pria di dalam novel.

"Jika misalnya Zakky poligami, apa reaksi Kak Jora," tanya Najwa.

"Aku poliandri, pakai cara-cara yang legal."

"Seperti apa?"

"Pertama mengkhulu'nya. Lalu nikah lagi dengan bintang film yang ganteng melebihi Zakky. Poliandri atau tidak, yang penting kan rasa adilnya. Sama-sama dua" (Khalieqy, 2004 : 115).

Kutipan di atas menunjukan bentuk perlawanan menjauhi orang lain, di mana Kejora lebih memilih menghindar atau menjauh dengan cara membalas perlakuan poligami dengan mengkhulu (menuntut cerai). Kemampuan Kejora dalam membalas ketimpangan yang berlaku di masyarakat merupakan bentuk perlawanan terhadap persepsi masyarkat yang selama ini berkembang bahwa yang boleh memiliki kekasih lebih dari satu adalah laki-laki saja. Keberanian Kejora menunjukan bahwa perempuan juga dapat melakukan hal yang sama dengan laki-laki, bahkan memiliki suami lebih dari satu.

\section{Faktor-faktor yang mempengaruhi perempuan untuk melakukan perlawanan dalam Novel Geni Jora Karya Abidah El Khalieqy}

Kejora merupakan perempuan yag memiliki pemikiran kritis terhadap pandangan perempuan di masyarakat. Semangatnya dalam menunjukan eksistensi perempuan yang agar setara dengan lakilaki membuat dirinya mengalami konflik psikologis dengan lingkungannya. Konflik tersebut membuat kejora mengalami pertentangan dalam dirinya. Hal tersebut tersirat dalam kutipan di bawah ini.

"Siapakah perempuan? Barisan kedua yang menyimpan aroma melati kelas satu? Semesta alam terpesona ingin meraihnya, memiliki dan mencium wanginya. Tetapi kelas dua? Siapakah yang menentuka kelas-kelas? Sehingga laki-laki adalah kelas pertama? Sementara Rabi'ah al Adawiyah laksana roket melesat mengatasi rangking dan kelas. Sebenarnya, kelas berapakah Hitler? George W. Bush? Mana lebih tinggi rankingnya, Ariel Sharon atau Fatimah Mernissi? Bukankah selain Abu Jahal, Fir'aun, Musailamah al Khadzdzab, Adam Wizehobart terdapat juga Maryam al Bathul, Balqis, Aisyah dan Fatimah az Zahra?" (Khalieqy, 2004 : $60)$.

Pertanyaan-pertanyaan yang muncul dalam diri Kejora. Hal tersebut dijadikan landasan berpikir Kejora sebelum Kejora mempertanyakan posisi dirinya dalam struktur keluarganya. Kutipan di atas menunjukan kecemasan dalam diri Kejora mengenai hakikat keberadaan perempuan di dalam keluarganya dan perempuan di dunia ini. Kecemasan dalam diri Kejora bertambah ketika Kejora mengalami konflik dengan saudara lakilakinya. 
"Kamu pasti nyontek, kata Prahara, adik lakilakiku.

"Seluruh kampung tahu, kamulah ahlinya nyontek," jawabku.

"Tetapi nenek tidak tahu."

"Akan kubeberkan semua rahasiamu, termasuk surat peringatan dari Bu Guru"

"Sepertinya kau belum perah merasakan bogem-ku?"

Pyarr... segelas susu ambyar (Khalieqy, 2004 : 60-61).

Kutipan di atas menunjukan bahwa Kejora berusaha menunjukkan eksistensi dirinya dalam hal akademis yang lebih baik daripada Prahara adik laki-lakinya. Konflik kedua bersaudara berbeda jenis kelamin tersebut menyebabkan nenek Kejora memberikan nasehat yang menyebabkan munculnya konflik psikologis dalam diri Kejora.

Dari atas kursinya, nenekku mulai ceramah. Bahwa perempuan harus selalu mau mengalah. Jika perempuan tidak mau mengalah, dunia ini akan jungkir balik berantakan seperti pecahan kaca. Sebab tidak ada laki-laki yang mau mengalah. Lakilaki selalu ingin menang dan menguasai kemenangan. Sebab itu perempuan harus siap menga-lah (pakai awalan 'me') (Khalieqy, 2004 : 61).

Konstruksi gender yang bersifat patriarkis di atas menimbulkan kecemasan dalam diri Kejora, yaitu kecemasan akan masa depan dirinya dan kecemasan akan masa depan perempuan. Kejora yang menentang budaya patriarki di dalam keluarganya mendapat pertentangan dari anggota keluarganya sendiri seperti Nenek dan Adiknya.

Konflik psikologis Kejora juga didapatkan dari Ayahnya. Dibesarkan dengan dua orang Ibu membuat Kejora merasakan pergolakan batin antara rasa kasihan dengan Ibu kandungnya dan rasa marah karena Ibunya mau menerima menjadi istri kedua Ayahnya. Kejora merasa bahwa perempuan tidak layak untuk diperlakukan tidak adil, karena poligami bagi Kejora adalah sebuah penindasan terhadap perempuan.

Dengan harta yang melimpah, Kejora merasa bahwa laki-laki telah menindas perempuan. Kepedihan yang dialami Ibunya membuat Kejora mengalami konflik psikologis antara dirinya dan Ayahnya. Hal tersebut tersirat dalam kutipan di bawah ini.
Kupikir Ibuku tertekan menjadi istri kedua. Itu bisa kubaca dari ekspresi wajahnya yang senantiasa masam saat melihat Ibu Fatmah pulang dari luar kota bersama ayah. Sekalipun banyak hadiah untuknya, tak dapat menghapus kesedihan yang memancar dari perasaan jiwanya yang tertekan.

Ibu pasti cemburu pada Ibu Fatmah," suatu kali aku bertanya.

"Apa Ibu Fatmah pantas dicemburui?"

"Ia begitu cantik, bukan?"

"Apa Ibu kurang cantik dari dia?"

"Tetapi Ibu kurang bahagia?"

Ibuku tertawa, ringan.

"Tahu apa kau tentag bahagia, anakku?" (Khalieqy, 2004 : 79-80).

Petikan di atas menunjukan bahwa Kejora mengalami konflik psikologis tentang arti kebahagiaan, bagaimana laki-laki mendapatkan kebahagiaan di atas penderitaan batin perempuan. Konflik psikologis yang dialami Kejora menjadikan kejora sadar bahwa budaya patriarki telah dialamiya bahkan di dalam lingkungan keluarganya sendiri.

Konflik Psikologis Kejora juga didapatkan dari pamannya. Paman yang dianggapnya sebagai pelindung ternyata menyimpan hasrat terhadap tubuh Kejora. Pengalaman masa kecil Kejora tersebut menyebabkan konflik psikologis dalam diri Kejora mengenai peran laki-laki bagi perempuan.

Setelah kalung kugenggam dengan gemetar, ternyata paman tidak melepas tanganku, ia tetap memegangnya, bahkan lebih erat. Ditariknya jemariku untuk diciumnya berulang-ulang. Tangan kanannya hendak meraih leherku saat kudengar sebuah langkah tersendat-sendat. Pastilah itu langkah nenek (Khalieqy, 2004 : 86).

Kutipan di atas meunjukan kecemasan Kejora terhadap Pamannya sendiri, kecemasan yang muncul tersebut mengakibatkan konflik psikologis dalam diri Kejora di mana trauma akan laki-laki membuatnya terjerumus dalam percintaan sesama jenis dengan teman satu pondoknya Elya.

"Aku mencintai-Mu dengan dua macam Cinta

Cinta rindu dan Cinta karena Engkau layak dicinta

Dengan Cinta rindu 
Kusibukan diriku dengan mengingat-ingat Mu selalu

Dan bukan selain-Mu

Sedangkan Cinta karena Kau layak dicinta Di sanalah Kau menyingkap hijab-Mu

Agar aku dapat memandang-Mu" (Khalieqy, 2004 : 90).

Puisi di atas merupakan puisi ungkapan cinta Elya kepada Kejora, perasaan cinta yang lebih dari sekedar sahabat. Dalam menghadapi perasaan cinta dari Elya, Kejora juga mengalami koflik psikologis dalam dirinya, yaitu perasaan nyaman saat dirinya berada di samping Elya yang berhadapan dengan cibiran dari lingkungan pondok saat hubungannya mulai diketahui oleh orang yang ia benci yaitu Sonya.

"Ternyata sedang dimabuk kepayang, to. Mesra benar. Ketua majelis tahkim tengah bercinta dengan aak buahnya . benar-benar sensasional".

Sesosok dari kegelapan tiba-tiba muncul. Sonya. Ia tengah membuntuti langkah kami. Pastilah untuk memata-mataiku bersama Elya. (Khalieqy, 2004 : 92).

Kecemasan yang muncul dalam diri Kejora merupakan benturan-benturan Id yang merepresentasikan nafsu seks sejenis tokoh utama perempuan Kejora dan Super Ego di dalam pondok pesantren yang dirasakan Kejora tidak sesuai dengan keadilan menurut pandangannya. Rasa cemas dan ketakutan tokoh utama senantiasa muncul dalam batin Kejora. "Aku begitu tertekan dan membiarkan Elya pergi sendiri menemui Sonya. Perasaanku teraduk-aduk dan pikiranku demikian ruwet. Kubayangkan jika fitnah itu menyebar, apa yang bakal terjadi? Tidak!” (Geni Jora, 2004 : 93).

Kecemasan dalam diri Kejora diakibatkan oleh konflik psikologis yag dialaminya. Dalam menghadapi konflik tersebut Kejora melakukan perlawanan dengan merepresi ingatannya mengenai kecemasan yang dialaminya. Hal tersebut tersirat dalam kutipan di bawah ini.

Kututup wajahku dan kutulikan pendengaranku. Kurasakan kengerian dari hantuhantu fitnah, seperti monster, puluhan monster, yang mengiringiku melompati jurang yang dalam dan gelap, di mana belukar segala ular dan belatung, bersatu memperebutkan kehidupanku, kesegaran jasad dan kemilau nuraniku. (Khalieqy, 2004 : 93).
Konflik psikologis Kejora juga didapatkan dari Zakky kekasih Kejora, Sebelum menjadi kekasih Kejora, Zakky adalah kekasih dari Elya sahabatnya. Konflik psikologis tokoh Kejora memberikan pengaruh terhadap hubungan antara Kejora dan Zakky. Perasaan cinta Kejora terhadap Elya dibenturkan terhadap rasa cintanya kepada Zakky. Kejora merasa cemas akan hubungannya dengan Zakky dapat merusak hubungannya dengan Elya sebagai sahabatnya.

Namun kini Zakky memelukku. Membisikan anggur ditelingaku sembari merampakan bunyi genderang cinta mengelilingi sanubariku. Air matamu menetes haru? Atau kau cemburu? Di tengah musim di mana anak manusia mencari hangat dari pasangannya, ayo, Elya bacakan lagi syair-syair Rabiah. Ke mana syairsyair itu menguap kini? Melaut ke dalam atmosfer bumikah? Atau terkapar bagai puing-puing kejayaan silam, di antara kalbu dan ruh kita, ia tenggelam di tengah bising gelombang permukaan dunia (Khalieqy, 2004 : 124).

Kutipan di atas meunjukan bentuk luapan psikologis Kejora yang di benturkan oleh konflik batin di dalam dirinya. Pertentangan yang mengakibatkan konflik psikologis dalam diri Kejora dan kekasihnya Zakki. Sehingga dapat disimpulkan bahwa tokoh Kejora mengalami berbagai konflik psikologis yang diakibatkan dari relasi hubungan dirinya dengan Elya dan Zakky kekasihnya.

Konflik psikologis Kejora disebabkan karena perbedaan sudut pandang perempuan dalam budaya patriarki yang muncul dikarenakan sterotip atau pelabelan terhadap sosok perempuan yang dianggap lemah, emosional, dan sebagai pekerja di ranah domestik dalam masyarakat yang keliru.

Sterotip yang muncul dalam kehidupan Kejora megenai perempuan ditemui dari kehidupan Kejora dan interaksinya dengan lingkungan, baik keluarga, teman dan kekasihya. Hal tersebut terlihat dalam kutipan berikut.

Dengan bermacam pergolakan yang dibawa dari negara masing-masing, mengenai kondisi kaum yang disayanginya, yang ternyata lemah dan terpinggirkan, yang menghuni pojokpojok sejarah, menempati baris-baris di luar pagina, yang kelaparan dan buta aksara, ditempeleng para suami dan diperkosa laki-laki. (Khalieqy, 2004 : 20) 
Kutipan di atas menunjukan berbagai ketidakadilan yang dialami perempuan yang mengakibatkan munculnya berbagai konflik di dalam diri mereka. Berbagai bentuk konflik yang dialami Kejora turut dalam membentuk karakter Kejora. Karakter tokoh Kejora yang berani melakukan perlawanan terhadap ketidakadilan gender tersebut didasari pengalaman dan berbagai konflik yang membuat Kejora menjadi perempuan yang tangguh dan pantang menyerah. Hal tersebut dapat dilihat dalam kutipan berikut.

Kala itu usiaku menginjak sembilan tahun, duduk di kelas lima sekolah dasar. Nenek telah menorehkan luka di hatiku. Dan luka itu terus menganga, setiap waktu. Fisik nenekku terus berevolusi, tetapi pikirannya tidak pernah ber-evolusi. Ia tetap duduk di atas kursinya dengan perintahperintahnya, sementara aku terus berlari menyongsong masa depan. Sekalipun sering terpukul oleh mulut jahatnya, pada dasarnya, jiwa dan semangatku mewarisi petualangan ayah. Itulah sebabnya, posisiku selalu berada di garis depan dan rankingku terus bertahan, sekalipun nenek senantiasa menghadang (Khalieqy, 2004 : 62)

Kutipan di atas menunjukan sifat pantang menyerah Kejora dalam menghadapi berbagai konflik yang muncul. Selain itu Kejora juga memiliki sifat teguh pada pendirian dan mandiri dalam menghadapi masalah atau konflik yang dihadapinya yang diceritakan melalui tokoh lain yaitu Asaav Muscovich.

Kau begitu konsisten dengan keyakinanmu. Inspirasimu merdeka dan kau berjalan di atas pijakan sangat kuat, tidak mudah hanyut bahkan oleh prahara kenikmatan. Bahkan di samping kekasihmu, kau terlihat sangat mandiri. Dari mulutmu, aku mendengar kumandang ayat suci menjadi begitu segar. Sangat lain (Khalieqy, 2004 : 141).

Kutipan tersebut menunjukan narasi yang menjelaskan keteguhan dan kemandirian tokoh Kejora dalam menghadapi konflik dan masalah yang dihadapinya. Kata "konsisten" dan "mandiri" menunjukan sikap tokoh Kejora dalam menghadapi berbagai kesulitan di dalam hidupnya.

\section{SIMPULAN}

Berdasarkan pembahasan tersebut, dapat disimpulkan hal sebagai berikut. Perlawanan perempuan secara psikoanalisis dibagi dalam tiga bentuk perlawanan antara lain, pergerakan mendekati orang lain, melawan orang lain, dan menjauhi orang lain. Dampak dari perlawanan tersebut, mengakibatkan perempuan mengalami berbagai macam mekanisme pertahanan diri seperti, pemindahan, sublimasi, identifikasi, represi, dan proyeksi.

\section{DAFTAR PUSTAKA}

Feist, J.G. 2010. Teori Kepribadian, Edisi 7. Jakarta : Salemba Humanika

Khalieqy, Abidah. 2004. Geni Jora. Bandung: Matahari.

Nurgiyantoro, Burhan. 1995. Teori Pengkajian Fiksi. Yogyakarta : Gadjah Mada Univercity Press.

Pradopo, Rachmad Djoko, 2002. Kritik Sastra Indonesia Modern. Yogyakarta: Gama Media.

Tong, Rosemarie Putnam. 2006. Feminist Thought Pengantar Paling Komprehensif Kepada Arus Utama Pemikiran Feminis. Yogyakarta: Jalasutra.

Wellek, Rene dan Austin Warren. 1963. Theory of Literature. Harcourt Brace Javanovich, Publisher, San Diego. New York. London.

Wellek, Rene \& Austin Wareen. 1989. Teori kesusastraaan (diterjemahkan oleh Melani Budianta). Jakarta : Gramedia. 